\title{
Evidence regarding external financing in manufacturing MSEs using Partial Least Squares regression
}

\author{
Eduard Gabriel Ceptureanu ${ }^{a}$, Sebastian Ion Ceptureanu ${ }^{a}$, Claudiu Herteliub \\ ${ }^{a}$ Department of Management, Bucharest University of Economic Studies, Romania bepartment of Statistics and Econometrics, Bucharest University \\ of Economic Studies, Romania
}

\begin{abstract}
The purpose of this study is to explore and explain the relationship between networking, external financing by banks and equity investors, and export effort in medium sized enterprises. Our research model was empirically tested on a sample of 143 MSEs in the manufacturing sector and our PLS results do not confirm the existence of a direct association between networking and export effort by MSEs. They show, however, that networking indirectly enhances MSEs' export effort through facilitating their access to equity financing and reducing managerial risks. Whilst networking are not found to be associated with a higher access to bank financing by MSEs, this type of external financing seems to have a greater impact on export effort than equity financing. This research it is one of the first studies to explore the role of networking with stakeholders in facilitating MSEs' access to external financing and to international markets and to merge these variables in a single model which consider simultaneously the MSE access to bank financing and to equity financing.
\end{abstract}

Keywords external financing; risk management; networking; stakeholders; equity financing

\section{Introduction}

Whilst various studies exist on how foreign network facilitate the firm's internationalization see e.g., Haahti et al. (2005), only limited research considered the role of networking with organizations in the firm's home country see e.g., Babakus et al. (2006) and Boehe (2013), and even fewer evidence exists about the particular role of networking with internal and external stakeholders, and research organizations in facilitating exports by medium sized enterprises (MSEs). Brandouy et al. (2015) considers it is essential to understand the role of this type of networking because local partnerships are easier to access and less costly to establish than foreign ones, due to cultural similarities, geographic proximity, and absence of language barriers between partners. This aspect is particularly important for MSEs given that they already experienced a negative impact from limited financial and managerial resources. Our paper contributes to this line of research by studying the effect of networking with local business partners on exports by MSEs.

Furthermore, MSEs may try to use different financing sources for their international activities such as bank loans, equity and trade credits. Because that external financing is still one of the main barriers to MSEs' internationalization, it is important for companies to understand how it can be overcome and whether local networking do improve MSEs' chances to acquire external financing from these different sources. However, existing study considers the effect of networking on one financing source at a time e.g., Fatoki et al. (2010) and Alexy et al. (2012) and only limited evidence exists about the relative impact of MSEs' networking on their access to different financing sources (Le et al. 2009). Our paper contributes to this literature by considering the effects of MSEs' networking on their access to financing by banks and by equity investors such as venture capitalists (VCs) and, furthermore, it also studies the influence of these sources of external financing on MSE exports.

At the same time, SMEs are frequently confronted with major challenges. Burgstaller et al. (2015) considers that, compared to larger enterprises, fewer MSEs have access to a wide resource base. Altman et al. (2010) emphasize that, because of the usually low equity ratio, they are relatively vulnerable to external events compared to larger enterprises. This illustrates that MSEs face various challenges and their survival is more easily threatened because of smaller set of financial resources. Risk management may help entrepreneurs to identify significant risks that could jeopardize the success or existence of the company in time to efficiently cope with them (Brustbauer, 2014). Misjudging or failing to recognize risks can have disastrous consequences, ranging from customer loss to damaging liability, decrease exports damage and even bankruptcy (Hollman et al. 1984). However, many MSEs do not- or not 
adequately- apply risk management practices, mostly because they cannot afford to rededicate resources because of their constraints (Marcelino- Sadaba et al. 2014).

The present study try to respond to these research gaps by answering the following question: What is the relationship between networking, external financing by banks and equity investors, and export effort in MSEs? To do so, we conduct an empirical analysis of data on 143 manufacturing MSEs, and test the direct and indirect relationships between the research constructs.

The remainder of this paper is organized as follows: A literature review of the relationships among networking, external financing, and exports is first presented and we developed five research hypotheses. We explained the research methodology, and present the findings. Finally, in the last sections, we discuss the results and present the conclusions, future work and limitations.

\section{Literature Review, Hypotheses and Research Model}

\subsection{Relationship between networking and external financing}

In order to finance their expansion, MSEs that do not have adequate resources will try to obtain external resources either through debt or equity financing. However, external investors such banks and equity funds are generally reluctant to finance MSEs' export activities due to several reasons, such as the uncertainty about whether the company has the necessary competences and managerial skills to manage its activities abroad (De Maeseneire et al. 2012); the complication of assessing the risks inherent to international activities (Steuer et al. 2007); the collateral assets are often located abroad (Riding et al. 2012).

Berger et al. (2007) considers that banks and other investors such as VCs are interested to have access to information about the firm's networking and business partnerships before deciding whether or not to invest in the MSE, and may contact the MSE's business partners such as its internal and external stakeholders to ask for comments about their past and current experience with the firm. Consistent and positive feedback is decisive for investors looking to know more about the potential investee e.g., Vassiloglu et al. (1990) and Kaffash et al. (2017). The results of Murthi et al. (1997) and Castellano et al. (2014) confirm that bankers use their social networks to search information on a potential customer's creditworthiness. Similarly, Alexy et al. (2012) show that VCs use their capital to identify the most promising investment opportunities. It can be argued that developing a strong networking are particularly important for MSEs interested in became more known on the markets, because it is less costly for investors to ask for referrals from a local partner that is known in the local economy and speaks the same language, than from a foreign partner.

In conclusion, inter-organizational networking can be expected to directly influence MSEs' access to external financing by banks and equity capital provided by shareholders other than the owner (Basso et al. 2003; Cerqueti et al. 2018). Empirically, some studies confirm that MSEs networking directly influence their bank financing (Le et al. 2009) and VCs financing (Avrikan et al. 2015); however, these researchers did not specifically focus on financing of exporting firms. Hence, we develop our two first hypotheses:

H1: Networking has a direct impact on bank financing.

H2: Networking has a direct impact on equity financing by outside investors.

\subsection{Relationship between external financing and internationalization by MSEs}

The relevant literature regarding exports suggests that international activities involve costs and risks that firms do not meet when doing business locally (Riding et al., 2012). Internationalization costs include operational costs (Bartoli et al. 2014), costs of adaptation of products to new customers' tastes and costs for penetrating a new market (Hallerbach et al. 2004), investments in their commercial and marketing activities, increase their manufacturing capacity, maintain higher inventory levels (Fethi et al. 2010). Potential exporters must therefore make sure they 
dispose of enough financial resources to cover these substantial costs before going international, which can be particularly challenging for MSEs (Camanho et al. 1999).

The literature recognizes the importance of financial markets in sustaining internationalization and maintains that exports are particularly vulnerable to credit imperfections (Ogryczak et al. 1999). Hence, Berger et al. (1997) considers companies whose access to external financing is less restricted are in a better position to do business on international level. Based on these assumptions, we develop our third hypothesis that expects bank financing to be directly associated with MSEs' export effort, defined as the proportion of export sales to total sales (Gao et al. 2009). Hence, we stipulate:

H3: Bank financing has a direct impact on MSEs' export effort.

George et al. (2005) suggest that an entrepreneur's attitude toward risk (i.e. export) depends on whether or not he shares the firm's ownership with external investors. If the owner is the sole proprietor, then failure in export activity could negatively affect his personal wealth and compromise his career, which is likely to negatively affect his disposition to engage in international activities. Alternatively, the presence of investors other than the owner may reduce the risk attached to exports given the financial support and the advice they provide.

More specifically, the literature suggests that the presence of VCs is likely to directly influence the MSEs export effort (Brouthers et al. 2005), because they not only look for investing in MSEs that are most likely to succeed and assist them financially, but also foresee opportunities to add value to the venture in the post-investment phase (Alexy et al. 2012). VCs perform an important governance function for their investees by providing management skills, experience, and expertise (Lockett et al. 2008). They provide strategic advice and help their investees in identifying the best growth opportunities, including possibilities of exporting their products/services to foreign markets. In addition, the VC's social network of professional, experts, and other VCs allows the entrepreneur to access unique resources and valuable information about future opportunities (Kaplan et al. 2004). Empirically, Lockett et al. (2008) show that the VCs' resources directly influence the MSE exports effort. Hence, our fourth hypothesis is:

H4: Equity financing by outside investors has a direct impact on MSEs' export effort.

\subsection{Relationship between networking and export activities by MSEs}

Empirically, the literature confirms that the MSE involvement in inter organizational networking has a direct effect on the firm's propensity to export see e.g., Amal et al. (2010) and Rodriguez et al. (2010) as well as on its export effort (Boehe 2013). Hellman et al. (2002) studied the roles of local versus foreign partners in facilitating the firm's success in entering foreign markets and found that both play a major role. In addition, Soderqvist et al. (2013) empirical results show that MSE networking are important for both pre-internationalization activities, such as exploring business ideas and opportunity recognition, and post-internalization activities in terms of resource acquisition and knowledge development about the international market. Hence our last hypothesis is:

H5: Networking has a direct impact on MSEs' export effort.

\subsection{Theoretical Model}

Although literature suggests several other factors that may influence export effort such as the firm's level of innovation, its culture, and its experience with exports see e.g., Berger et al. (1997) and Cerqueti et al. (2013), we have included in this research only two control variables (i.e. firm size and the entrepreneur interest in international scalability), for the following reasons: (a) these two variables are available from the database we used; b) the impact of these two variables on exports in the particular context of MSEs has been demonstrated in past empirical research.

Firm Size- is considered to be an indicator of available internal resources and access to external resources, including external financing. Pinho (2007) also identified firm size as a factor in whether the enterprise is able to absorb the 
costs of its strategy and the risks of international business. We anticipate a direct relationship between firm size and export effort.

Entrepreneur's Interest in International Scalability- the literature on exporting MSEs identifies the owner as the key variable in the decision to move onto international markets (Utz et al. 2013). Amal et al. (2010) considers that an entrepreneur's interest in international scalability appears to be a major determinant of whether or not the firm will engage in foreign business. Okpara et al. (2010) finds that MSEs' owner who have a strong international orientation tend to be more dynamic in researching information on foreign markets and are more inclined to take part in international trade shows, both of which allow them to gather a wealth of information likely to reduce the uncertainty and risks of their international activities. Empirically, Kazem et al. (2006) found a direct and substantial relationship between an entrepreneur's commitment to international scalability and the firm's export performance. We therefore expect a direct link between the entrepreneur's interest in international scalability and MSEs' export effort. Figure 1 presents the research model and hypotheses.

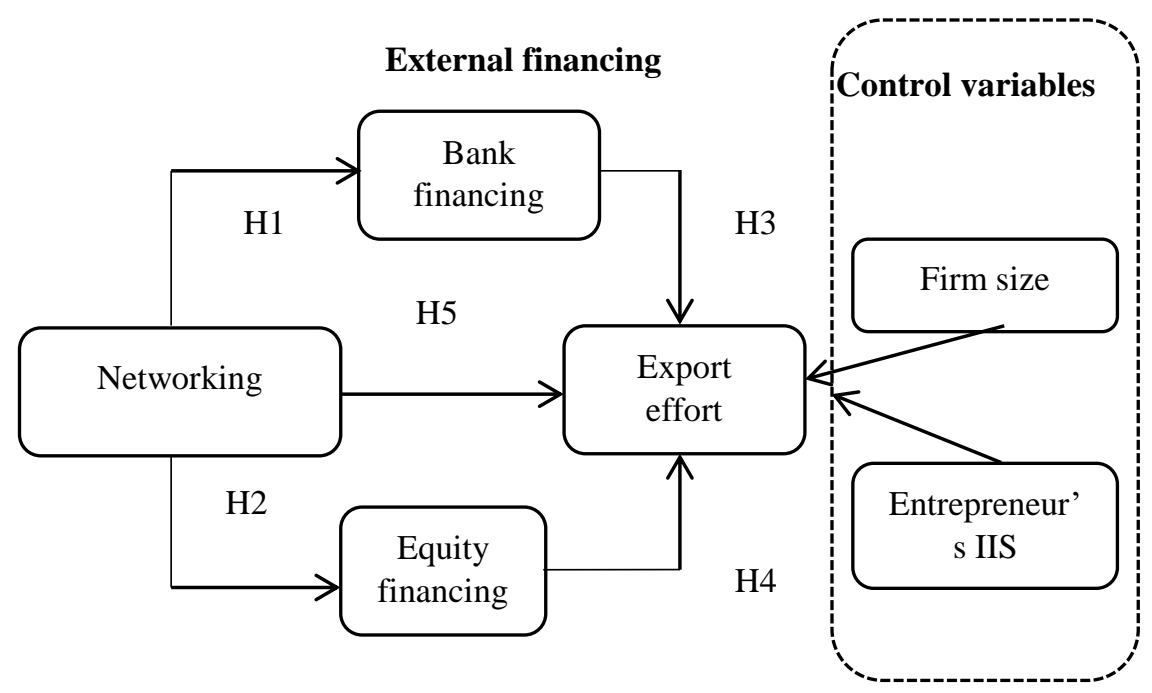

Fig 1 Theoretical Model

\section{Methodology}

\subsection{Sample and Descriptive Statistics}

The initial data with 1247 medium size enterprises from manufacturing sector was obtained from Romanian National Trade Registration Office in 2014. Using this data, we start to cooperate with 946 of MSEs in a European Fund Project regarding competitiveness. Hence, we create our project private database in the context of a performance diagnostic service offered to manufacturing MSEs from 2015 to 2017. Entrepreneurs were asked to complete a 12-page questionnaire and to add their financial statements for the last 3 years. Only firms for which we had all the data needed in this research were included in our final sample of 143 MSEs. Information collected is voluntarily provided by the participating firms. Therefore, we cannot pretend that our sample represents Romanian manufacturing MSEs, but only MSEs interested in improving their performance by the usage of a benchmarking performance measurement system. It should, however, be noted that the characteristics of the sample included in the database are comparable to those of Romanian manufacturing MSEs in terms of industrial sectors represented- low to medium technology intensity, and size for MSEs involved in international activities (Ceptureanu et al. 2017).

As shown in Table 1, the sampled MSEs have between 50 and 249 employees, with an average of 83.4 employees, complying with the European Union's definition of MSEs, which refers to businesses with 50-249 employees. The percentage of their sales to external markets varies from 0 to 97 percent, with an average of 24.3 percent, whereas the euro amount of bank financing per employee varies between 0 and 175,500 EUR, with an average of 25,644 EUR. Table 1 also shows that 18 percent of responding MSEs are financed with a venture capital, while 16 percent 
are financed with informal investors. The owner's interest in international activities seems to be high in our sample as 59 percent of the respondents indicated that their international activities result from organized and intentional exporting.

Table 1

Descriptive Statistics $(N=143)$.

\begin{tabular}{|c|c|c|c|c|}
\hline & Mean & SD & Min & Max \\
\hline Number of employee & 83.40 & 87.88 & 50 & 249 \\
\hline Export Effort (Percentage of Sales to foreign market) & 0.243 & 0.286 & 0 & 0.970 \\
\hline Bank Financing in EUR per Employees (Line of Credit/Number of Employees) & 25,644 & 42,438 & 0 & 175,500 \\
\hline Participation of venture capital in financing (yes $=1 ; \mathrm{no}=0$ ) & 0.182 & 0.145 & 0 & 1 \\
\hline Participation of informal investors in financing $(\mathrm{yes}=1 ; \mathrm{no}=0$ ) & 0.161 & 0.110 & 0 & 1 \\
\hline Entrepreneur's IIS (proactive export $=1$; reactive export $=0$ ) & 0.593 & 0.520 & 0 & 1 \\
\hline $\begin{array}{l}\text { Total of answers about whether or not the MSE cooperate with R\&D organizations } \\
\text { in all organizational functions (yes }=1 ; n \mathrm{n}=0 \text { ) }\end{array}$ & 0.635 & 0.926 & 0 & 4 \\
\hline $\begin{array}{l}\text { Total of answers about whether or not the MSE cooperates with internal } \\
\text { stakeholders in all organizational functions }(\mathrm{yes}=1 ; \mathrm{no}=0)\end{array}$ & 1.428 & 1.369 & 0 & 5 \\
\hline $\begin{array}{l}\text { Total of answers about whether or not the MSE cooperates with external } \\
\text { stakeholders in all organizational functions }(\mathrm{yes}=1 ; \mathrm{no}=0)\end{array}$ & 1.767 & 1.402 & 0 & 5 \\
\hline
\end{tabular}

Organizational functions $=$ manufacturing/distribution/logistics/design and R\&D / sales

The number of areas of networking between the sample firms and R\&D organizations (research centres and universities) varies between 0 and 4 , with a mean of 0.635 . Responses for areas of networking with internal and external stakeholders vary between 0 and 5 with averages of 1.428 and 1.767 , respectively. It seems, therefore, that networking with external stakeholders is the most present in our sample, followed by networking with internal stakeholders, then with R\&D organizations. This may be explained by the nature of activities of the sampled MSEs that belong to the manufacturing industry, which are considered to be medium-to-low technology (OECD 2011 for industry classification).

\subsection{Construct and Variable Measurement}

The research variables and constructs were measured as follows:

Export Effort- following Katsikeas et al. (2000), it is measured as the ratio of MSE's sales to foreign markets to their total sales.

Networking- is measured by the number of areas in which the MSE has business contacts (networks) with internal and external stakeholders and R\&D organizations. For each of these partners, respondents were asked to indicate whether or not (yes $=1$ and no $=0$ ) they develop network relationships in manufacturing, distribution, logistics, design and R\&D, and sales. For each partner, the entrepreneur's responses were added and the total obtained was used as an indicator of the level of networking with that partner. Three scores (one for internal stakeholders, one for external stakeholders, one for R\&D organizations) were then used as reflective indicators of the construct networking for each MSE.

Bank Financing- was measured with one questionnaire item asking the respondents to specify the EUR amount obtained by the MSE through a line of credit with a bank. Given the spread of firm sizes in our sample, the value of the line of credit was divided by the number of employees.

Equity Financing- equity financing is measured by two items that indicate the participation of shareholders other than the owner in capital equity. The respondents indicated whether venture capital firms and informal investors who are not family members held voting shares in the firm's equity (for each of these two investors: yes $=1$; no $=0$ ).

Firm Size- We used EU recommendation 2003/361. According to the recommendation, a medium size enterprise is a company which employ fewer than 250 but more than 50 persons and which have an annual turnover not exceeding EUR 50 million but more than 10 million, and/or an annual balance sheet total not exceeding EUR 43 million but more than 10 million. 
Entrepreneur's Interest in International Scalability - the entrepreneur's Interest in International Scalability (IS) was measured via a multiple choice question that asked the owner(s) whether exports were in response to: (1) unexpected orders; (2) his/her own informal initiatives; or (3) his/her own organized initiatives. The variable is rated 1 if the respondent replied (3) and 0 otherwise.

\subsection{Variable Correlations and t-Tests}

Correlations among the items used to measure the research variables and constructs are presented in Table 2, which shows three main results. First, networking with $R \& D$ organizations is directly and substantial related to the three types of financing by venture capital, banks, and informal investors, while networking with internal stakeholders is directly associated only to financing through informal investors. Networking with external stakeholders is not linked with any type of financing. MSEs who have networking with R\&D organizations seem therefore to have better access to external financing, probably due to their degree of innovation that reduces commercial risk and presents a potential return sought by investors. In addition, networking with external stakeholders may be seen as a substitute to financing by banks and equity. When an MSE cooperates with its external stakeholders, it will have access to commercial credit from them, which decreases its need to seek other sources of financing.

Table 2

Spearman Correlation Matrix

\begin{tabular}{|c|c|c|c|c|c|c|c|c|c|}
\hline & 1 & 2 & 3 & 4 & 5 & 6 & 7 & 8 & 9 \\
\hline Firm size & 1 & & & & & & & & \\
\hline \multirow{2}{*}{ Expert effort } & $0.281^{* * *}$ & 1 & & & & & & & \\
\hline & $\mathbf{0}$ & & & & & & & & \\
\hline \multirow{2}{*}{ Bank financing } & 0.1 & $0.271^{* * * *}$ & 1 & & & & & & \\
\hline & 0.174 & 0.001 & & & & & & & \\
\hline \multirow{2}{*}{ Venture capital financing } & $0.141^{*}$ & $0.233^{* * *}$ & $0.187^{* *}$ & 1 & & & & & \\
\hline & 0.077 & 0.003 & 0.02 & & & & & & \\
\hline \multirow{2}{*}{ Informal investor financing } & 0.072 & 0.071 & 0.123 & $0.273^{* * *}$ & 1 & & & & \\
\hline & 0.373 & 0.37 & 0.11 & 0.001 & & & & & \\
\hline \multirow{2}{*}{$\begin{array}{l}\text { Entrepreneur's interest in } \\
\text { international scalability }\end{array}$} & $0.171^{* *}$ & $0.374^{* * *}$ & 0.04 & 0.05 & -0.04 & 1 & & & \\
\hline & 0.032 & $\mathbf{0}$ & 0.603 & 0.41 & 0.541 & & & & \\
\hline \multirow{2}{*}{$\begin{array}{l}\text { Networking with R\&D } \\
\text { organizations }\end{array}$} & $0.145 *$ & 0.121 & $0.154^{*}$ & $0.205^{* *}$ & $0.191^{* *}$ & $-0.179^{* *}$ & 1 & & \\
\hline & 0.06 & 0.129 & 0.053 & 0.01 & 0.014 & 0.025 & & & \\
\hline \multirow{2}{*}{$\begin{array}{l}\text { Networking with internal } \\
\text { stakeholders }\end{array}$} & $0.185^{* *}$ & $0.147^{*}$ & 0.02 & 0.119 & $0.239^{* *}$ & -0.044 & $0.211^{* *}$ & 1 & \\
\hline & 0.01 & 0.066 & 0.802 & 0.13 & 0.003 & 0.561 & 0.007 & & \\
\hline \multirow{2}{*}{$\begin{array}{l}\text { Networking with external } \\
\text { stakeholders }\end{array}$} & 0.082 & 0.011 & 0.033 & 0.101 & 0.129 & -0.001 & 0.122 & $0.471^{* * *}$ & 1 \\
\hline & 0.2 & 0.875 & 0.61 & 0.1988 & 0.101 & 0.984 & 0.119 & 0 & \\
\hline
\end{tabular}

Statistically relevant correlations are in bold. ${ }^{*} p<.1 ; * * p<.05 ; * * * p<.01$

Among the three types of networking, only networking with internal stakeholders is directly and relevant associated with export effort. Networking with internal stakeholders is also positively and relevant associated with networking with R\&D organizations and networking with external stakeholders.

More, both bank financing and venture capital financing are positively correlated with export effort, a result that confirms our assumptions. Financing by informal investors other than the owner seems, however, not to influence the sampled MSEs' effort of exports.

Ultimately, we performed a t-test to compare firms with a venture capital to those without. The results presented in Table 3 show that MSEs with a venture capital investor receive more financing from banks and informal investors, have higher export effort, and cooperate more with R\&D organizations than MSEs without venture capital, which is 
consistent with Brouthers et al. (2005) argument regarding the presence of a venture capital (VC) in MSEs which tends to facilitate export activities.

Table 3

Comparison of MSEs with Access/No Access to VCs

\begin{tabular}{lccc}
\hline & No VCs (N=108) & With VCs (N=35) & t- Test Statistic \\
Firm size & 80.70 & 88.70 & 1.24 \\
Entrepreneur's IIS & 0.56 & 0.61 & 0.66 \\
Export Effort & 0.18 & 0.38 & $2.79^{* *}$ \\
Bank Financing (Line of credit/ Number of & 17.858 EUR & 30.649 EUR & $1.87^{*}$ \\
Employees) & 0.16 & 0.44 & $2.93^{* *}$ \\
Participation of Informal Investor in Financing & 0.53 & 1.08 & 2.48 \\
Networking with R\&D Organizations & 1.36 & 1.77 & 1.58 \\
Networking with internal stakeholders & 1.71 & 2.02 & 1.21 \\
Networking with external stakeholders & & & \\
\hline
\end{tabular}
$* p<.10 ; * * p<.05$

\section{Results and discussions}

\subsection{Measurement Model}

We use Partial Least Squares (PLS) with SmartPLS software 3 (Ringle et al. 2015) to test our hypotheses. We chose this method because of its ability to process latent variables, to analyse models with several dependent variables and to estimate direct and indirect relationships between variables (Chin et al. 1999). Before presenting the structural model results, we need to evaluate construct unidimensionality, reliability, and discriminant validity for the two constructs measured with multiple items, that is, networking and equity financing. Unidimensionality is satisfied when indicators' loadings on the construct they are meant to measure are above 0.4 (Johnson et al. 1998). As shown in Figure 2, this condition is met for all indicators. As shown in Table 4, the reliability and discriminant validity are verified. 


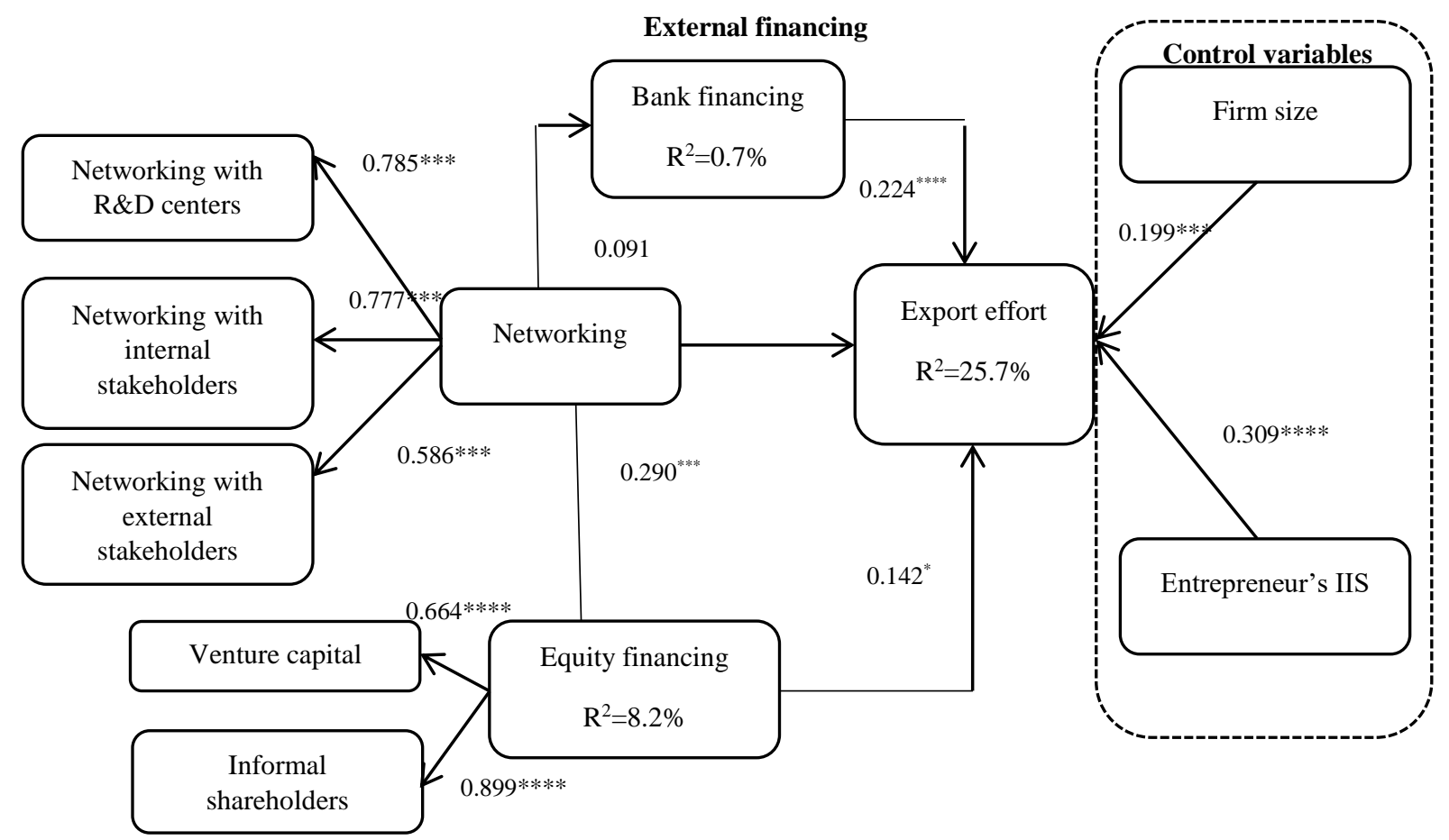

Fig 2 Test of the Research Model (PLS Results, $N=143$ ).

$* p<.1, * * p<.05, * * * p<.01, * * * * p<.001$ (one tailed)

\section{Table 4}

Reliability and Discriminant Validity

\begin{tabular}{lccccccc}
\hline & CR & 1 & 2 & 3 & 4 & 5 & 6 \\
Bank financing & 1 & $\mathbf{1}$ & & & & & \\
Networking & 0.77 & 0.01 & $\mathbf{0 . 5 1}$ & & & & \\
Equity financing & 0.77 & 0.03 & 0.07 & $\mathbf{0 . 6 1}$ & & & \\
Export effort & 1 & 0.06 & 0.02 & 0.05 & $\mathbf{1}$ & $\mathbf{1}$ & \\
Firm size & 1 & 0.00 & 0.03 & 0.01 & 0.07 & 0.03 & $\mathbf{1}$ \\
Entrepreneur's IIS & 1 & 0.00 & 0.02 & 0.00 & 0.12 & \\
\hline
\end{tabular}

$\mathrm{CR}=$ composite reliability; Diagonal (in bold) = average variance extracted (AVE).

Sub-diagonal $=$ Shared Variance $=(\text { correlations })^{2}$

\subsection{Structural model and results}

PLS results reported in Figure 2 show that the general model explains 26.8 percent of the variance in exports effort, which can be considered as satisfactory (Falk et al. 1992). As a robustness check, we also ran the model using Stata and very similar results were found. Overall, PLS findings provide a partial support to our research model. Networking with the three types of partners considered in this study (R\&D organizations, internal and external stakeholders) are found to directly and relevant influence the MSEs' access to equity financing $(\beta=0.290, \mathrm{p}<.1)$, but do not seem to be related to bank financing $(\beta=0.093, p>0.1)$. Hence, H1 is rejected but H2 is supported. Next, $\mathrm{H} 3$ and $\mathrm{H} 4$ are also supported because export effort is positively influenced by both bank financing $(\beta=0.224$, $\mathrm{p}<.001)$ and equity financing $(\beta=0.144, \mathrm{p}<.1)$. Besides, bank financing appears to have a greater effect on export 
effort than equity financing. Finally, our last hypothesis H5 is not supported. The PLS results show a statistically irrelevant relation among networking and export effort $(\beta=0.072, p>0.1)$.

In summary, these results show that networking have an indirect effect on export effort by MSEs through facilitating these firms' access to equity financing. The results for the control variables are consistent with expectations. Firm size $(\beta=0.201, p<.01)$ and entrepreneur's interest in international scalability $(\beta=0.313, p<.001)$ have relevant direct effects on export effort, which is consistent with other studies (Sousa et al., 2008). In addition, entrepreneur's orientation to export seems to be the most important explanatory factor of export effort among all variables considered in the study.

This study identifies the relationship between networking, external financing by banks and equity investors, and export effort in MSEs examining the underlying, mediating processes in these links, offering new theoretical and pragmatic insights in two respects. First, our results confirm that MSEs' networking do indeed positively influence their access to equity financing by investors such as VCs. Interestingly, our results show that the influence of networking on the firm's access to bank financing is irrelevant. This result may be due to the fact that we combined the firm's networking with internal and external stakeholders, and R\&D organizations in one construct, while each of these partners may influence differently the MSE's access to financing by banks. Le et al. (2009) found that customer networking positively influenced the firm's bank financing by giving it access to trade credits, which reduces its need to apply for bank loans, while suppliers networking reduced it. These findings may also suggest that banks rely extensively on hard information to make credit decisions and prefer to use the financial data shown in the firm's financial statements, as they may be perceived as more objective and valid. On the other hand, investors in the MSE equity may rely more on soft information because they share the investee's risks that are not necessarily reflected in their financial statements. Informal investors may also feel more confident about their investment in a given MSE that is used to cooperate with other organizations because that lowers their perceived moral hazard and increase their level of trust. Second, result shows that both equity and bank financing directly affect the firms' export effort. The PLS analyses show that the influence of bank financing on export effort by MSEs is greater than the influence of equity financing. The important significance of bank financing suggests that if access to this source of external funding were limited, MSEs would reduce their exporting efforts, which may negatively affect the pace of development of these firms' activities and of the economy as a whole.

From the risk management point of view, our paper complies with the results of the study by Gilmore et al. (2004) who showed that entrepreneurs frequently use their personal networks to manage risky situations. Therefore, close relationships with banks and VCs may be regarded as another technique to manage risks successfully. Gilmore et al. (2004) showed that, in addition to personal networks, SMEs often maintain similarly close relationships with existing clients in the hope of gaining more profits. Similarly, the study of Delerue et al. (2009), also showed that entrepreneurs tend to enter into a cooperative relationship when they perceive a high level of relational risk or when they hope to gain a future competitive advantage on exports. In line with the studies mentioned above, the largescale study by Kim et al. (2014) also found that networking is a frequently used risk-mitigation strategy in MSEsaccording to their results, mostly for coping with technology, financial and market risks.

\section{Conclusions and future work}

This research it is one of the first studies to explore the role of networking with stakeholders in facilitating MSEs' access to external financing and to international markets and to combine these variables in a single model which consider simultaneously the MSE access to bank financing and to equity financing. Our research model was empirically tested on a sample of 143 MSEs in the manufacturing sector and our PLS results do not confirm the existence of a direct association between networking and export effort by MSEs. They show, however, that networking indirectly enhances MSEs' export effort through facilitating their access to equity financing. Whilst networking are not found to be associated with a higher access to bank financing by MSEs, this type of external financing seems to have a greater impact on export effort than equity financing.

This article offers valuable results for MSE entrepreneurs and governments. Our findings show that financing constraints that hinder MSEs' ability to do business abroad could be partially overcome if these firms develop networking relationships with other organizations. It also suggests that it is important for export-oriented firms to offer adequate training to employees and managers about how to cooperate properly and effectively with the 
stakeholders. It is therefore particularly important for MSEs to plan and manage well their network relationships and the associated hazards. Also, policy makers should assist MSEs in implementing adequate planning and competence development activities to ensure the success of networking.

Finally, our results also show the importance of the financial support provided by banks for the success of exports by MSEs. Bank financing was found to be even more important than equity financing by VCs and other external investors. To facilitate MSE internationalization, governments, banks, and MSEs should work together to make these firms' access to bank financing easier.

Future studies may focus on how the presence of VCs and informal investors in the MSE equity may facilitate these firms' access to bank financing. Given that equity investors play an important consultancy role, maybe their presence would reduce bankers' perceived uncertainty and motivate them to invest in exporting activities by MSEs. It would also be interesting to study the effect of networking on other sources of export financing used by MSEs, such as trade credit, European Union project funds, lease financing, and government loans or grants to stimulate exports.

Despite the important contributions of this study, it is important to mention that we identified a number of limitations that are mainly methodological, and which can be seen as interesting avenues for future research. First, an interesting avenue to explore would be to replicate this study in other countries and other sectors of activities. Second, we only measured the presence of VCs and informal investors but did not have knowledge about the importance of their participation in the firm's capital nor about the length of their relationship with the company. These variables may be important to explore in future researches as they can be indicators of the level of these investors' influence on the MSE export decisions and activities. Third, given the use of secondary data from a private database, we were not able to take into account the length and strength of the relationships between the MSE and its different partners, which may affect the influence of network relationships on access to external financing and on exports.

In conclusion, the present research findings show how critical it is for entrepreneurs who focus to expand their activities in international markets to invest time and resources in developing networking with financial stakeholders. These network relationships may indirectly support the expansion of the MSE in international markets through enhancing the firm chances to obtain external funding. Also, public bodies that provide assistance MSEs in their internationalization efforts should not limit themselves to increase the number of free trade agreements and changing policies only, but should also support MSEs to develop networking with other local enterprises, and to work on building a solid reputation.

\section{References}

Alexy, O. T., J. H. Block, P. Sandner, \& Ter Wal, A.L. (2012). Social Capital of Venture Capitalists and Start-up Funding, Small Business Economics, 39, 835-851.

Altman, E.I., Sabato, G., \& Wilson, N. (2010). The value of non-financial information in small and medium-sized enterprise risk management. Journal of Credit Risk, 6, 95-127.

Amal, M., Rocha F, \& Filho, A. (2010). Internationalization of Small- and Medium-Sized Enterprises: A Multi-Case Study, European Business Review, 22, 608-623.

Avkiran, N. K., \& Alpert, K. (2015). The influence of co-authorship on article impact in OR/MS/OM and the exchange of knowledge with Finance in the twenty-first century. Annals of Operations Research, 235, 5173.

Babakus, E., U. Yavas, \& Haahti, A. (2006). Perceived Uncertainty: Networking and Export Performance: A Study of Nordic SMEs, European Business Review, 18, 4-13.

Bartoli, F., G. Ferri, \& Murro, P. (2014). Bank Support and Export: Evidence from Small Italian Firms, Small Business Economics, 42, 245-262. 
Basso, A., \& Funari, S. (2003). Measuring the performance of ethical mutual funds: a DEA approach. Journal of the Operational Research Society, 54, 521-531.

Berger, A. N., \& Frame, W.S. (2007). Small Business Credit Scoring and Credit Availability, Journal of Small Business Management, 45, 5-22.

Berger, A. N., \& Humphrey, D. B. (1997). Efficiency of financial institutions: International survey and directions for future research. European Journal of Operational Research, 98, 175-212.

Boehe, D. (2013). Collaborate at Home to Win Abroad: How Does Access to Local Network Resources Influence Export Behavior?, Journal of Small Business Management, 51, 167-182.

Brandouy, O., Kerstens, K., \& Van de Woestyne, I. (2015). Frontier-based vs. traditional mutual fund ratings: A first backtesting analysis. European Journal of Operational Research, 242, 332-342.

Brouthers, L. E., \& Nakos, G. (2005). The Role of Systematic International Market Selection on Small Firms' Export Performance, Journal of Small Business Management, 43, 363-381.

Brustbauer, J.(2014). Enterprise risk management in SMEs: towards a structural model. International Small Business Journal, 34, 70-85.

Burgstaller, J., \& Wagner, E. (2015). How do family ownership and founder management affect capital structure decisions and adjustment of SMEs? Evidence from a bank-based economy. The Journal of Risk Finance, 16, 73-101.

Camanho, A. S., Dyson, R. G., The, I., \& Sim, T. (1999). Efficiency, size, benchmarks and targets for bank branches: An application of data envelopment analysis. Journal of the Operational Research Society, 50, 903-915.

Castellano, R. \& Cerqueti, R. (2014). Mean-Variance portfolio selection in presence of infrequently traded stocks, European Journal of Operational Research, 234, 442-449.

Ceptureanu, E.G., Ceptureanu, S.I. \& Popescu, D.I. (2017). Relationship between Entropy, Corporate Entrepreneurship and Organizational Capabilities in Romanian Medium Sized Enterprises, Entropy, 19, 412.

Cerqueti, R., Falbo, P., Guastaroba, G. \& Pelizzari, C. (2013). A Tabu Search heuristic procedure in Markov chain bootstrapping, European Journal of Operational Research, 227, 367-384.

Cerqueti, R., Rotundo, R. \& Ausloos., M.(2018). Investigating the configurations in cross shareholding: A Joint Copula- Entropy Approach, Entropy, 20, 134.

Chin, W. W., \& Newsted, P.R. (1999). Structural Equation Modeling Analysis with Small Samples Using Partial Least Squares, in Statistical Strategies for Small Sample Research. Ed. R. Hoyle. Thousand Oaks, CA: Sage Publications, 307-341.

De Maeseneire, W., \& T. Claeys (2012). SMEs, Foreign Direct Investment and Financial Constraints: The Case of Belgium. International Business Review, 21, 408-424.

Delerue, H., \& Perez, M. (2009). Unilateral commitment in alliances: an optional behavior. Journal of Management Development, 28, 134-149.

EU recommendation 2003/361.

Falk, R., \& Miller, N. (1992). A Primer for Soft Modeling. Akron, OH: University of Akron Press.

Fatoki, O., \& Odeyemi, A. (2010). Which New Small and Medium Enterprises in South Africa Have Access to Bank Credit, International Journal of Business and Management, 5, 128-136. 
Fethi, M. D., \& Pasiouras, F. (2010). Assessing bank performance with operational artificial intelligence techniques: A Survey. European Journal of Operational Research, 204, 189-198.

Gao, G. Y., J. Murray, M. Kotabe, \& Lu, J. (2009). A 'Strategy Tripod' Perspective on Export Behaviors: Evidence from Domestic and Foreign Firms Based in an Emerging Economy, Journal of International Business Studies, 41, 377-396.

George, G., J. Wiklund, \& Zahra, S.A. (2005). Ownership and the Internationalization of Small Firms, Journal of Management, 31, 210-233.

Gilmore, A., Carson, D., \& O'Donnell, A. (2004). Small business owner-managers and their attitude to risk. Marketing Intelligence \& Planning, 22, 349-360.

Haahti, A., V. Madupu, U. Yavas, \& Babakus, E. (2005). Cooperative Strategy, Knowledge Intensity and Export Performance of Small and Medium Sized Enterprises, Journal of World Business, 40, 124-138.

Hallerbach, W., Ning, H., Soppe, A., \& Spronk, J. (2004). A framework for managing a portfolio of socially responsible investments. European Journal of Operational Research, 153, 517-529.

Hellmann, T., \& Puri, M. (2002). Venture Capital and the Professionalization of Start-up Firms: Empirical Evidence, Journal of Finance, 53, 169-197.

Hollman, K.W., \&Mohammad-Zadeh, S.(1984). Risk management in small business. Journal of Small Business Management, 22, 7-55.

Johnson, R. A., \& Wichern, D.W. (1998). Applied Multivariate Statistical Analysis, 4th ed. Upper Saddle River, NJ: Prentice Hall.

Kaffash, S., \& Marra, M. (2017). Data envelopment analysis in financial services: a citations network analysis of banks, insurance companies and money market funds, Annals of Operations Research, 253, 307-344.

Kaplan, S. N., \& Stromberg, P. (2004). Characteristics, Contracts, and Actions: Evidence from Venture Capitalist Analyses, The Journal of Finance, 59, 2177-2210.

Katsikeas, C.S., Leonidou, C.L., \& Morgan, A.N. (2000). Firm-Level Export Performance Assessment: Review, Evaluation, and Development, Journal of the Academy of Marketing Science, 28, 493-511.

Kazem, A., \& Van Der Heijden, B. (2006). Exporting Firms' Strategic Choices: The Case of Egyptian SMEs in the Food Industry, SAM Advanced Management Journal, 71, 21-33.

Kim, Y., \& Vonortas, N.S.(2014). Managing risk in the formative years: evidence from young enterprises in Europe. Technovation, 34, 454-465

Le, N.T.B., \& T. Nguyen (2009). The Impact of Networking on Bank Financing: The Case of Small and Medium Enterprises in Vietnam. Entrepreneurship Theory and Practice, 33, 867-887.

Lockett, A., Wright, M., Burrows, A., Scholes, L., \& Paton, D. (2008). The Export Intensity of Venture Capital Backed Companies, Small Business Economics, 31, 39-58.

Marcelino-Sádaba, S., Pérez-Ezcurdia, A.,Echeverría Lazcano, A.M., \& Villanueva, P.(2014). Project risk management methodology for small firms. International Journal of Project Management, 32, 327-340.

Murthi, B.P.S., Choi Y.K., \& Desai, P. (1997). Efficiency of mutual funds and portfolio performance measurement: A non- parametric approach, European Journal of Operational Research, 98, 408-418.

OECD (2011). ISIC Rev.3 Technology Intensity Definition. Paris: OECD Directorate for Science, Technology and Industry.Available at: http://www.oecd.org/science/innovationinsciencetechnologyandindustry/48350231.pdf (accessed July 12, 2018). 
Ogryczak, W., \& Ruszczynski, A. (1999). From stochastic dominance to mean-risk models: Semi deviations as risk measures. European Journal of Operational Research, 116, 33-50.

Okpara, J. O., \& Koumbiadis, N.J. (2010). Strategic Export Orientation and Internationalization Barriers: Evidence from SMEs in a Developing Economy, Journal of International Business and Cultural Studies, 4, 1-10.

Pinho, J.C. (2007). The Impact of Ownership, International Marketing Review, 24, 715-734.

Riding, A., Orser, B.J., Spence, M., \& Bélanger, B. (2012). Financing New Venture Exporters, Small Business Economics, 38, 147-163.

Ringle, C., M., Wende, S., \& Becker, J.-M. (2015). SmartPLS 3. Bönningstedt, Germany: SmartPLS, Available at: http://www.smartpls.com (accessed April 5, 2018).

Rodriguez, A., \& Nieto, M.J. (2010). The Internationalization of Knowledge-Intensive Business Services: The Effect of Collaboration and the Mediating Role of Innovation, The Service Industries Journal, 32, 10571075.

Soderqvist, A., \& Chetty, S.K. (2013). Strength of Ties Involved in International New Ventures, European Business Review, 25, 536-552.

Sousa, C. M. P., Martinez-López, F. G., \& Coelho, F. (2008). The Determinants of Export Performance: A Review of the Research in the Literature between 1998 and 2005, International Journal of Management Reviews, 10, 343-374.

Steuer, R. E., Qi, Y., \& Hirschberger, M. (2007). Suitable-portfolio investors, non-dominated frontier sensitivity, and the effect of multiple objectives on standard portfolio selection. Annals of Operations Research, 152, 297-317.

Utz, S., Wimmer, M., Hirschberger, M., \& Steuer, R. (2013). Tri-criterion inverse portfolio optimization with application to socially responsible mutual funds. European Journal of Operational Research, 234, 491498.

Vassiloglou, M., \& Giokas, D. (1990). A study of the relative efficiency of bank branches: An application of Data Envelopment Analysis. Journal of the Operational Research Society, 41, 591-597. 